\title{
Establishment and Characterization of an Epithelial Cell Line, SGE1, from Isolated Rat Renal Glomeruli
}

\author{
Masayasu Yamada ${ }^{1}$, Makoto Kawaguchi ${ }^{2}$, Haruo Takamiya $^{3}$, \\ Hiroyoshi Wada ${ }^{2}$, and Tohru Okigaki ${ }^{1}$ \\ ${ }^{1}$ Division of Cell Biology, Shigei Medical Research Institute, Okayama 701-02, Japan \\ ${ }^{2}$ Department of Pediatrics, Hyogo College of Medicine, Nishinomiya 663, \\ Japan, and ${ }^{3}$ Department of Internal Medicine, Shigei Medical Research \\ Hospital, Okayama 701-02, Japan
}

\begin{abstract}
An epithelial cell line, designated as SGE1, has been established from isolated rat renal glomeruli. SGE1 cells are able to grow continuously in a serum-free medium at similar growth rates to those in the medium containing serum. Quantitative studies of the cells in the serum-free condition demonstrated that SGE1 cells required a collagen type I or IV, fibronectin, or laminin-coated substratum for adhesion and growth, and among them, collagen type I and IV were most effective. Essential medium supplements for the adhesion and growth were epidermal growth factor and transferrin, respectively, and both effects were noticeably enhanced with linoleic acid. Morphological observation found that in a monolayer culture, SGE1 cells formed domes, and in a collagen embedding culture, they formed cystic spheres having features of a simple cuboidal epithelium, polarized formation of microvilli and tight junctions as well as a lateral cell membrane with cytoplasmic projections. In addition, SGE1 cells expressed Fx1A antigens, which are nephritogenic antigens on their microvilli.
\end{abstract}

The development of extended serial passage of homogeneous glomerular cells in culture may allow us to facilitate the study of individual roles of glomerular cell physiology and pathology, since the glomerulus is a complex structure composed of four major cell types: visceral and parietal epithelial cells, mesangial and endothelial cells. It was found that each of these cells exhibited outgrowth in the primary culture. Several studies have confirmed culture conditions for the selective growth of different types of glomerular cells from isolated glomeruli, and reviews of the results have recently been published $(27,44)$. However, long-term culturing by extended serial passage of glomerular epithelial cells have not yet been described in detail. Recently, MacKay et al. (30) reported, however, the establishment of a permanent cell line of cloned glomerular epithelial cells from a line of mice, transgenic for the early region of a simian virus 40 , although the cloned cells expressed transformed phenotypes such as lack of contact-inhibited growth and anchorage-independent growth.

We previously attempted to study the effects of culture substratum and medium components on the primary outgrowth of epithelial cells from explanted rat 
glomeruli (50). Results showed that the epithelial cells predominantly grew out from explanted glomeruli on collagen type IV-coated substratum and either in a serumfree or $1 \%$ fetal calf serum (FCS) containing medium supplemented with insulin (Ins), transferrin ( $\mathrm{Tr}$ ), selenium (Se), fatty acids-free bovine serum albumin (BSA), linoleic acid (LA), and epidermal growth factor (EGF) (50). When 10\% FCS was added, there was a graded decrease of epithelial cells within several days; in contrast, fibroblastic cells probably of messangial origin $(27,44)$, began to assume prominence (50). Moreover, outgrowth of the epithelial cells was definitely dependent on the nature of the substratum because the cells actively outgrew from glomeruli resided on collagen type IV-coated substratum, whereas they did not show outgrowth on uncoated or BSA-coated plastic substratum at all (50).

In the present study, we report the establishment and characterization of a normal epithelial cell line derived from isolated rat renal glomeruli.

\section{MATERIALS AND METHODS}

Animals. Three- to 4-week old male Wistar rats (Clea Japan, Inc., Tokyo) weighing 60 to $80 \mathrm{~g}$ were used.

Culture medium and substratum. The basal medium used was a $1: 1$ mixture of Dulbecco's modified Eagle's medium and Ham's F12 medium (Nissui Seiyaku Co., Ltd., Tokyo). The medium supplements were Ins (Collaborative Research, Inc., Bedford, MA), Tr (Sigma Chemical Co., St. Louis, MO), Se (Sigma Chemical Co., St. Louis, MO), BSA (Sigma Chemical Co., St. Louis, MO), LA (Sigma Chemical Co., St. Louis, MO), EGF (Earth Chemical Co., Ltd., Ako) and FCS (M.A. Bioproducts, Walkersville, MD). The basal medium supplemented with $5 \mu \mathrm{g} / \mathrm{ml} \mathrm{Ins,} 5 \mu \mathrm{g} / \mathrm{ml} \mathrm{Tr}, 5 \mathrm{ng} / \mathrm{ml} \mathrm{Se}, 1 \mathrm{mg} / \mathrm{ml} \mathrm{BSA}, 5 \mu \mathrm{g} / \mathrm{ml} \mathrm{LA}$ and $10 \mathrm{ng} / \mathrm{ml}$ EGF was designated as DHFs.

To coat plastic culture dishes (Costar, Co., Cambridge, MA), the dishes were covered with acid soluble collagens $(25 \mu \mathrm{g} / \mathrm{ml}$ in $0.013 \mathrm{M} \mathrm{HCl}$, Cell matrix I-P or $-4-$, Nittagelatine, Osaka), FN $(25 \mu \mathrm{g} / \mathrm{ml}$ in Dulbecco's phosphate buffered saline (PBS), Collaborative Research, Inc., Bedford, MA) or laminin (LN, $25 \mu \mathrm{g} / \mathrm{ml}$ in PBS, Collaborative Research, Inc., Bedford, $\mathrm{MA}$ ), and incubated for $2 \mathrm{~h}$ at $37^{\circ} \mathrm{C}$, after which they were washed repeatedly with PBS.

Isolation and primary culture of glomeruli. Isolation of glomeruli was performed according to Harper's method (19). Briefly, the kidney cortices were dissected and cut into small pieces. The cortical pieces were pressed with a spatula through a stainless steel screen of 200$\mu \mathrm{m}$-pore mesh. They were rinsed with PBS through screens of $150-\mu \mathrm{m}$-pore and $75-\mu \mathrm{m}$-pore meshes. The isolated glomeruli were retained on the $75-\mu \mathrm{m}$-pore mesh. The glomeruli with a purity of at least $95 \%$ were confirmed under a phase contrast microscope. A negligible amount of tissue contaminants appeared to be tubular fragments.

Isolated glomeruli were rinsed twice in PBS, and incubated with trypsin $(0.2 \%, 1: 250$, DIFCO Laboratories, Detroit, MI) for $10 \mathrm{~min}$ at $37^{\circ} \mathrm{C}$. The trypsinized glomeruli composed of encapsulated and decapsulated ones were washed in PBS with $10 \%$ calf serum (CS, M.A. Bioproducts, Walkersville, MD) in order to inactivate the trypsin activity, and then washed twice in PBS. The glomeruli suspended in an appropriate medium were explanted at 1000 glomeruli $/ 35 \mathrm{~mm}$ dish. The culture condition used was with collagen type IV-coated substratum and DHFs medium with or without 1 or $10 \% \mathrm{FCS}$ at $37^{\circ} \mathrm{C}$ under $5 \% \mathrm{CO}_{2} / 95 \%$ air.

Subculture of glomerular epithelial cells. The passage of cloned epithelial cells (SGE1) was carried out at a $1: 10$ split ratio by trypsinization. The dishes were washed twice in PBS 
followed by $0.05 \%$ trypsin and $0.02 \%$ ethylenediaminetetraacetic acid, disodium salt (Wako Pure Chemical Industries, Ltd., Osaka) in PBS. After 5 min at $37^{\circ} \mathrm{C}$, the detached cells were washed in $10 \%$ CS containing PBS to inactivate trypsin activity, washed twice in PBS, then centrifuged. The cell pellets were resuspended in DHFs medium and the suspended cells were inoculated in collagen type IV-coated dishes and cultured in DHFs medium supplemented with $10 \% \mathrm{FCS}$ at $37^{\circ} \mathrm{C}$ under $5 \% \mathrm{CO}_{2} / 95 \%$ air.

Collagen embedding culture. Eight volumes of $3 \mathrm{mg} / \mathrm{ml}$ collagen solution (Cellmatrix 1A, Nittagelatine, Osaka) was mixed both with 2 volumes of a $2: 1$ mixture of $10 \times$ basal medium and $0.34 \mathrm{M} \mathrm{NaOH}$, and kept on ice to prevent gelation. With SGE1 cells $\left(1.0 \times 10^{5}\right.$ cells $/ \mathrm{ml}$ ), Ins, Tr, Se, BSA, LA, EGF, and FCS were added to a cold gel mixture at final concentrations of $5 \mu \mathrm{g} / \mathrm{ml}, 5 \mu \mathrm{g} / \mathrm{ml}, 5 \mathrm{ng} / \mathrm{ml}, 1 \mathrm{mg} / \mathrm{ml}, 5 \mu \mathrm{g} / \mathrm{ml}, 10 \mathrm{ng} / \mathrm{ml}$, and $10 \%$, respectively. Five $\mathrm{ml}$ of the mixture was overlaid on a $5 \mathrm{ml}$ base of gelled collagen in $60 \mathrm{~mm}$ culture dishes (Costar, Co., Cambridge, MA) and allowed to gel at room temperature. After the layer had gelled, the cells were fed with DHFs medium supplemented with $10 \%$ FCS for 10 days.

Adhesion assay. Single cells suspended in basal medium with or without the supplements tested were inoculated at $2.0 \times 10^{4}$ cells $/ 35 \mathrm{~mm}$ dishes on collagen type I- or IV-, FN-, or LNcoated plastic substratum, or uncoated plastics. The cells were allowed to settle and adhere at $37^{\circ} \mathrm{C}$ under $5 \% \mathrm{CO}_{2} / 95 \%$ air. After $18 \mathrm{~h}$, any unattached cells were removed by PBS rinsing. The remaining and adhered cells were trypsinized, and counted by a hemocytometer. Cell viability was then estimated by the Trypan blue exclusion test (39).

Growth assay. SGE1 cells $\left(2.0 \times 10^{4}\right.$ cells $/ 35 \mathrm{~mm}$ dish $)$ were inoculated with DHFs medium with or without $10 \%$ FCS on collagen type I- or IV-, FN-, or LN-coated plastic substratum, or uncoated plastics and allowed to adhere for $18 \mathrm{~h}$. The adhered cells were washed with the basal medium, then cultured in the basal medium with or without the supplements tested. At the end of the culture period, the cells were collected and the viable cells were counted.

Light microscopy. In a monolayer culture, SGE1 cells were observed under a phase-contrast inverted microscope and photographed. In a collagen embedding culture, collagen gels were washed in PBS, fixed in $10 \%$ buffered formalin, embedded in paraffin, cut into $3 \mu \mathrm{m}$ thicknesses, and stained with periodic acid methenamine silver (PAM).

Electron microscopy. Confluent SGE1 cells cultured on collagen type I-coated LAB-TEK chamber slides (Miles Laboratories, Inc., Naperville, IL) in DHFs medium were washed twice in PBS and fixed in a mixture composed of $2 \%$ paraformaldehyde, $2.5 \%$

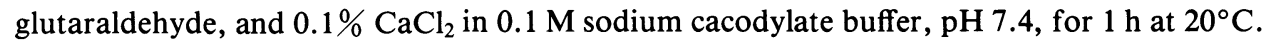
The slides were washed in cold $0.05 \mathrm{M}$ sodium cacodylate buffer, $\mathrm{pH} 7.4$, containing $0.2 \mathrm{M}$ sucrose, postfixed in $2 \% \mathrm{OsO}_{4}$ in $0.05 \mathrm{M}$ sodium cacodylate buffer, $\mathrm{pH} 7.4$, containing $0.2 \mathrm{M}$ sucrose for $1 \mathrm{~h}$ at $4^{\circ} \mathrm{C}$, dehydrated through an ethanol series and embedded in TAAB resin. Ultrathin sections of the fixed cells were stained with uranyl acetate and lead citrate, and examined under a transmission electron microscope.

Collagen gels in which cell aggregates or cysts had formed were directly transferred from the medium to a fixative. The fixed gels were then removed from the dishes, cut in pieces, and further sectioned. The ultrathin sections were stained with uranyl acetate and lead citrate, and examined with a transmission electron microscope.

Antibodies. Rabbit antiserum to Fx1A antigens was provided by Dr. F. Shimizu (Dept. of Immunol., Inst. Nephrol., Niigata Univ., Niigata). Rabbit antiserum to human factor VIII was purchased from Nordic Immunology (Tilburg, The Netherlands). Fluorescein isothiocyanate (FITC)-conjugated goat antiserum to rabbit IgG was purchased from Cappel Laboratories (Malvern, PA). Horse radish peroxidase (HRP)-conjugated goat antiserum to 
rabbit IgG was purchased from Medical and Biological Laboratories Co., Ltd. (Nagoya).

Immunofluorescence. SGE1 cells were grown on collagen type I-coated LAB-TEK chamber slides. The slides were washed twice in PBS and fixed for $20 \mathrm{~min}$ in $3 \%$ buffered formalin. The slides were then washed for $30 \mathrm{~min}$ in 3 changes of PBS and the fixed cells were permeabilized by immersing them in 1\% Nonidet P-40 (Wako Pure Chemical Industries, Ltd., Osaka) for $20 \mathrm{~min}$ at room temperature, and washed for $30 \mathrm{~min}$ in 3 changes of PBS. The slides were incubated at $37^{\circ} \mathrm{C}$ for $45 \mathrm{~min}$ in diluted rabbit antiserum or nonimmune rabbit serum as a control, each diluted $1: 10$ in PBS, then washed for $30 \mathrm{~min}$ in 3 changes of PBS. The slides were then incubated at $37^{\circ} \mathrm{C}$ for $45 \mathrm{~min}$ in FITC-goat antiserum to rabbit IgG diluted $1: 20$ in PBS, washed for $30 \mathrm{~min}$ in 3 changes of PBS and mounted with $30 \%$ glycerin in PBS. The cells were examined by a fluorescent microscope. When cell surface proteins were examined, the membrane permeabilization with Nonidet P-40 was omitted from the above procedure.

Immunoelectron microscopy. Localization of Fx1A antigens on the SGE1 cell surface was ascertained by immunoelectron microscopy. Confluent SGE1 cells on collagen type Icoated dishes in DHFs medium were washed twice in PBS and then fixed with periodatelysine-paraformaldehyde at $4{ }^{\circ} \mathrm{C}$ for $2 \mathrm{~h}$. The dishes were washed for $30 \mathrm{~min}$ in 3 changes of PBS, incubated at room temperature for $30 \mathrm{~min}$ in goat serum diluted 1:10 in PBS, and washed again for $30 \mathrm{~min}$ in 3 changes of PBS. The dishes were then incubated at room temperature for $15 \mathrm{~min}$ in rabbit antiserum to Fx1A antigens or nonimmune rabbit serum as a control, each diluted $1: 50$ in PBS, washed for $30 \mathrm{~min}$ in 3 changes of PBS, and incubated at room temperature for $15 \mathrm{~min}$ in HRP-goat antiserum to rabbit IgG diluted 1:20 in PBS. After washing for $30 \mathrm{~min}$ in 3 changes of PBS, the cells were fixed at $4{ }^{\circ} \mathrm{C}$ for $20 \mathrm{~min}$ in $2 \%$ glutaraldehyde in PBS, then washed again for $30 \mathrm{~min}$ in 3 changes of PBS. 3,3'-Diaminobenzidine (Wako Pure Chemical Industries, Ltd., Osaka) was added as chromogen for $10 \mathrm{~min}$. After washing for $30 \mathrm{~min}$ in 3 changes of PBS, the cells were scraped into PBS with a rubber policeman, then pelleted $(1,000 \times \mathrm{g})$. Finally, the pellets were postfixed with $1 \% \mathrm{OsO}_{4}$ for $30 \mathrm{~min}$ at room temperature, dehydrated, embedded in TAAB resin, and sectioned for transmission electron microscopy.

Assessment of $\mathrm{C} 3 \mathrm{~b}$ receptors. To identify C $3 \mathrm{~b}$ receptors, the cells on collagen type Icoated dishes in DHFs medium with or without FCS were kept at room temperature for $30 \mathrm{~min}$ with a suspension of antibody and complement-sensitized bovine erythrocytes (OxEAC, Otsuka Seiyaku Co., Ltd., Tokyo). The positive control used was mouse peritoneal macrophages and the negative control was cells of the rat liver epithelial cell line, RL34. A cell was considered rosette-positive if it possessed five or more adherent bovine erythrocytes.

Enzyme assay. SGE1, and MDCK cells derived from the canine renal tubular epithelium were independently cultured on collagen type I-coated dishes in DHFs medium with $10 \%$ FCS. MDCK cells were donated by Dr. A. Sato (Dept. of Dental Materials and Technol., School of Dent., Tokyo Med. and Dent. Univ., Tokyo). Once they became confluent, both types of cells were washed twice in PBS, then scraped with a rubber policeman into a $3 \mathrm{ml}$ PBS/60 mm dish. The cell samples were placed on ice and sonicated by a microtip at a half maximum power for 30 seconds. A portion of the cell lysates was frozen at $-20^{\circ} \mathrm{C}$ for further analysis. $\gamma$-glutamyl transpeptidase $(\gamma$-GTP, EC 2.3.2.2) was measured by a commercially available assay kit ( $\gamma$-GTPC-Test Wako, Wako Pure Chemical Industries, Ltd., Osaka). The enzyme activity was expressed as international units (IU). Alkaline phosphatase (ALP, EC 3.1.3.1) activity was measured by an automatic analyzer (Hitachi type 712, Hitachi Koki Co., Ltd., Tokyo). The enzyme activity was expressed as KingArmstrong Units (KAU). Both enzyme activities were normalized to the total cellular DNA content in cell lysates, measured by the method of Fiszer-Szafarz et al. (11). 


\section{RESULTS}

Establishment of a glomerular epithelial cell line. Our previous study (50) and present study have demonstrated that isolated glomeruli which were explanted on the collagen type IV-coated substratum and cultured in DHFs medium with $1 \%$ FCS, produced polygonal epithelial cell colonies, although large and flattened cells having irregular cytoplasmic extensions and a small number of fibroblastic cells coexisted as well. In contrast, addition of more than 10\% FCS into the medium resulted in overgrowth of the fibroblastic cells. When such an epithelial cell colony was maintained in DHFs medium with $1 \%$ FCS, the cells began to grow slowly within 10 days, after which the growth rate gradually accelerated. After one month, a large colony composed of small cuboidal cells developed. During the one-month period, other types of cells were almost eliminated from the dish with a fine-tip glass pole. At this time, the first subculture of the epithelial cells was carried out. Subsequently, the epithelial cells were cloned by selection of a colony which developed from a single cell. The cloned epithelial cells were actively grown and serially subcultured for more than 1 year and at the present, were over the 120th passage. The cloned cells exhibited distinctive polygonal epithelial shape and formation of cobblestone-like sheets (Fig. 1).

Chromosomal analysis was carried out at around the 30th passage. Ninety percent of the cells showed a diploid chromosome number with a modal number of 42 (range 38-46). About 10\% of the cells showed a tetraploid karyotype. Moreover, we ascertained that the cells did not grow in soft agar even at a high density $\left(10^{5}\right.$

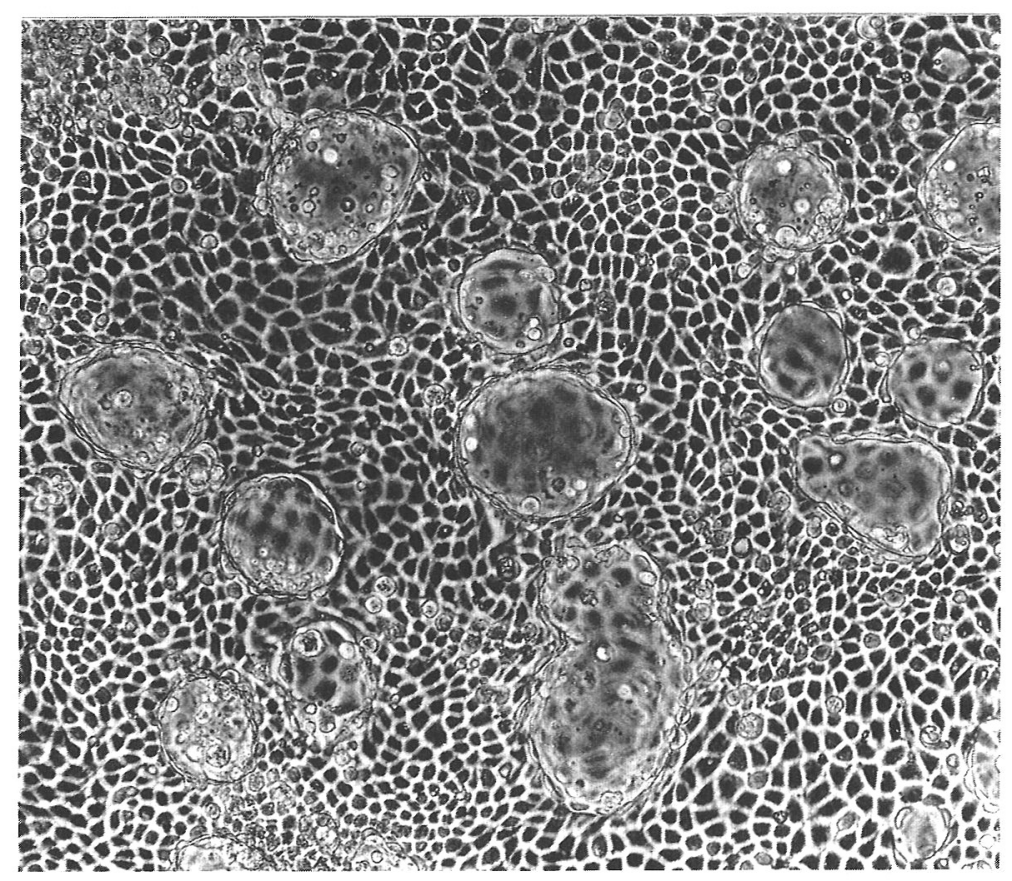

Fig. 1. Confluent SGE1 cells after the 30th passage maintained on the collagen type I-coated substratum in DHFs medium with $10 \%$ FCS. Note the cobblestone-like sheet and the domes. $\times 400$. 
cells/ml), and did not produce any tumors in syngeneic newborn rats, suggesting that the epithelial cells are not malignant in nature.

Concluding the establishment of a normal cell line, we designated the cell line SGE1. The cells between the 20th and the 50th passage were subsequently monitored for adhesion, growth, morphological and functional studies.

Serum effects. SGE1 cells have normally been grown with a twice a week passage at a $1: 10$ split ratio in DHFs medium with 10\% FCS. We initially attempted to analyze the effects of FCS on the growth of SGE1 cells. The cells (approximately $1.6 \times 10^{4}$ cells $/ 35 \mathrm{~mm}$ dish) which adhered on the collagen type IV-coated substratum $18 \mathrm{~h}$ after inoculation with DHFs medium containing 10\% FCS were washed once in PBS and cultured in DHFs medium with or without FCS (1 or 10\%) for 7 days. As shown in Fig. 2, the cells actively grew in the serum-free medium at a doubling time of $21.6 \mathrm{~h}$ and the growth rate was almost comparable to that in the medium with each concentration of FCS.

Substratum effects. The nature of the substratum is known to be an important factor for regulation of cell adhesion, growth and differentiation $(42,47,49,51)$. We have previously demonstrated that outgrowth of epithelial cells from primary glomerular explants requires collagen type IV-coated substratum (50). Therefore, we examined the effects of the substratum, especially FN, LN, collagen type I and IV, which are major components of the extracellular matrix (Table 1).

When SGE1 cells $\left(2.0 \times 10^{4}\right.$ cells $/ 35 \mathrm{~mm}$ dish $)$ were inoculated with DHFs medium, only about $20 \%$ of the cells adhered to uncoated plastics within $18 \mathrm{~h}$. When the dishes were coated with FN, LN or collagen type I or IV, 70\% of the inoculated cells adhered to both types of collagens, whereas FN and LN were less effec-

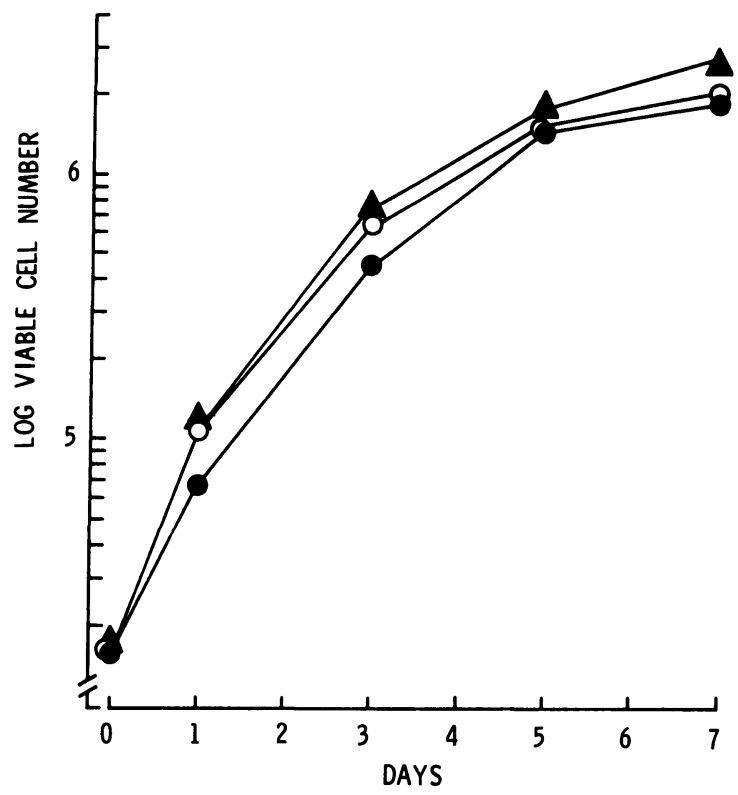

Fig. 2. Effects of FCS on the growth of SGE1 cells. The cells $\left(2.0 \times 10^{4}\right.$ cells $/ 35 \mathrm{~mm}$ dish $)$ were inoculated on a collagen type IV-coated substratum with DHFs medium containing $10 \%$ FCS. Adhered cells (approximately $1.6 \times 10^{4}$ cells $/ 35 \mathrm{~mm}$ dish) were cultured for 7 days in DHFs medium alone (๑), with $1 \%$ FCS $(O)$ or $10 \%$ FCS $(\Delta)$. Values represent the mean $(n=6)$. 
TABLE 1. EFFECTS OF THE NATURE OF THE SUBSTRATUM ON ADHESION AND GROWTH OF SGE1 CELLS

\begin{tabular}{lcccc}
\hline \multirow{2}{*}{ Substrata } & \multicolumn{2}{c}{ Adhesion } & & Growth \\
\cline { 2 - 3 } \cline { 5 - 5 } & $\begin{array}{c}\text { Adhered Cell Number } \\
\left(\times 10^{-4} \text { cells } / 35 \mathrm{~mm} \text { dish }\right)\end{array}$ & \% Adhesion & & $\begin{array}{c}\text { Cell Number at Day } 5 \\
\left(\times 10^{-5} \text { cells/35mm dish }\right)\end{array}$ \\
\hline Plastic & $0.40 \pm 0.02$ & $20.0 \pm 1.0$ & & $1.00 \pm 0.78$ \\
FN & $0.90 \pm 0.02$ & $45.2 \pm 0.8$ & & $6.00 \pm 0.38$ \\
LN & $0.91 \pm 0.04$ & $45.0 \pm 1.0$ & & $6.25 \pm 0.43$ \\
Collagen type I & $1.45 \pm 0.03$ & $72.7 \pm 1.3$ & & $15.00 \pm 1.29$ \\
Collagen type IV & $1.43 \pm 0.05$ & $71.3 \pm 2.3$ & & $14.25 \pm 2.34$ \\
\hline
\end{tabular}

The cells $\left(2.0 \times 10^{4}\right.$ cells $/ 35 \mathrm{~mm}$ dish $)$ were inoculated in various types of substrata with DHFs medium and after $18 \mathrm{~h}$ incubation, the number of adhered cells was counted. The cells adhered on various types of substrata were further cultured for 5 days in DHFs medium. At the end of the culture period, the cell number was counted. Values represent the mean $\pm \operatorname{SD}(n=3)$.

tive, with $45 \%$ adherence. All of the substrata, except for the uncoated plastics, also caused spreading and growth of the cells in 5 days of culture, however, the growth rates were much higher on collagen type I and IV compared to those on FN and LN. There was no difference between collagen type I and IV in the growth effects.

These results indicate that the nature of the substratum is an important factor for adhesion and growth of SGE1 cells.

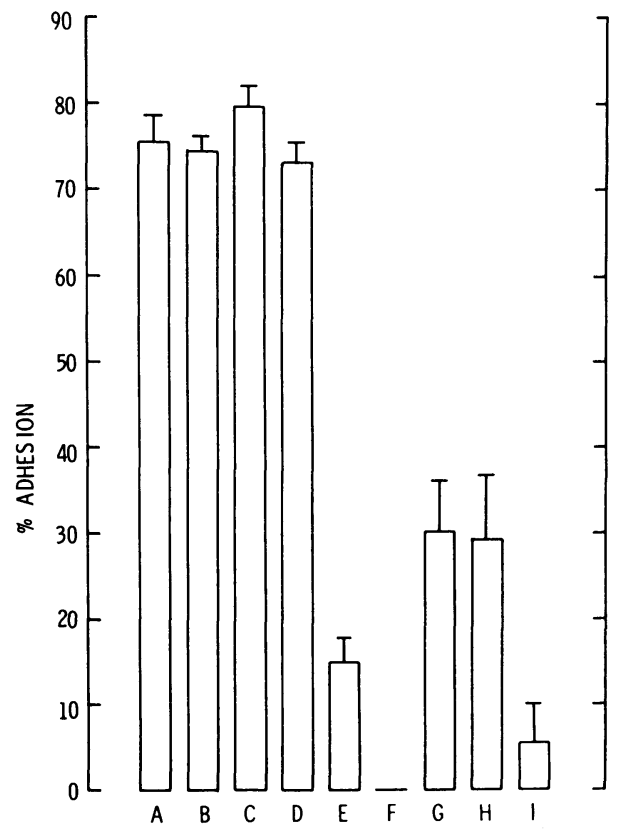

Fig. 3. Effects of supplement deletion from DHFs medium on SGE1 cell adhesion to collagen type Icoated substratum. The cells $\left(2.0 \times 10^{4}\right.$ cells $/ 35 \mathrm{~mm}$ dish $)$ were inoculated with each test medium. Values represent the mean \pm SD of $\%$ adhesion $(n=4)$. A: no deletion, B: -Ins, C: -Tr, D: -Se, E: -EGF, F: BSA, G: -LA, H: -(BSA + LA), I: basal medium. 
Medium supplement effects. The effects of medium supplements on cell adhesion and growth were evaluated in the condition without serum. All supplements were tested by individually deleting each factor from the DHFs medium. First, SGE1 cells were inoculated at $2.0 \times 10^{4}$ cells $/ 35 \mathrm{~mm}$ dish on collagen type I-coated substratum with test medium and after $18 \mathrm{~h}$ of incubation, the number of cells adhered was counted (Fig. 3). In DHFs medium, 75\% of the inoculated cells adhered to the substratum, whereas in the basal medium without any supplement, only $5 \%$ of the cells had adhered. Although deletion of Ins, Tr, or Se from DHFs medium had no influence on cell adhesion, deletion of either EGF or LA showed a much lower rate of adhesion than that of the complete DHFs medium. The rate of adhesion in EGF deletion (15\%) was significantly lower than that in LA deletion $(30 \%)$. The deletion of BSA caused cell rupture several hours after seeding, but when both BSA and LA were deleted, the inoculated cells adhered at a rate similar to that in the LA-deleted DHFs medium without cell rupture, indicating that BSA acted as a detoxification agent for LA.

As shown in Fig. 4, EGF added to basal medium with BSA exerted the stimulating effect in a dose-dependent manner. The stimulating action of EGF was effective at any concentration greater than $1 \mathrm{ng} / \mathrm{ml}$ and the maximal effect was reached at $10 \mathrm{ng} / \mathrm{ml}$, although BSA itself had no activity. Moreover, the stimulating effect of EGF synergistically increased by adding LA, although LA itself had only weak activity, the rate of adhesion being $10 \%$ (Fig. 4). A combination of EGF and LA exerted a similar adhesion-stimulating effect to that in the DHFs medium. The results indicate that EGF is intrinsically essential for cell adhesion.

In subsequent experiments, the trypsinized cells were inoculated on collagen type

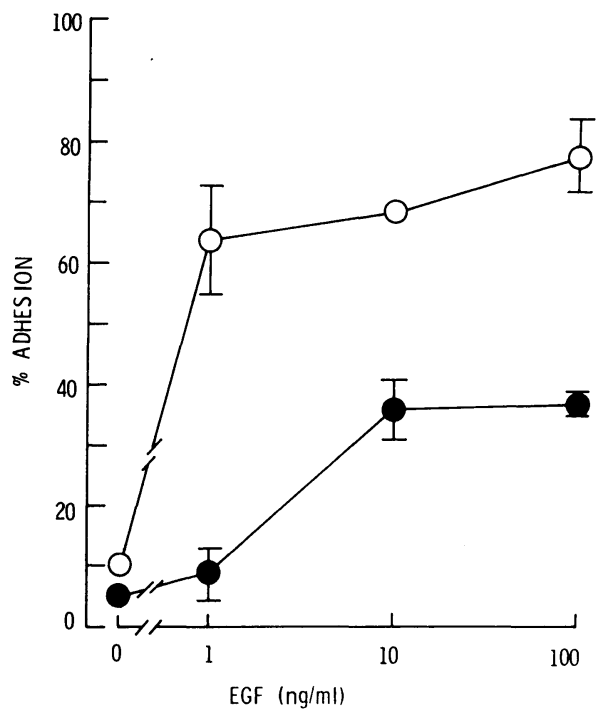

Fig. 4. Effects of EGF and/or LA on adhesion of SGE1 cells to collagen type I-coated substratum. The cells $\left(2.0 \times 10^{4}\right.$ cells $/ 35 \mathrm{~mm}$ dish $)$ were inoculated with various concentrations of EGF containing basal medium with $\mathrm{Se}(5 \mathrm{ng} / \mathrm{ml})$ and BSA $(1 \mathrm{mg} / \mathrm{ml})$, in the presence $(\bigcirc)$ or absence $(\bullet)$ of LA $(5 \mu \mathrm{g} / \mathrm{ml})$. After $18 \mathrm{~h}$ of incubation, the number of adhered cells was counted. Values represent the mean \pm SD of $\%$ adhesion $(n=4)$. 
I-coated substratum with DHFs medium, and $18 \mathrm{~h}$ later the adhered cells (approximately $1.4 \times 10^{4}$ cells $/ 35 \mathrm{~mm}$ dish) were further cultured in the basal medium, complete DHFs medium or supplement-deleted DHFs media for 5 days. The cell number was counted at the end of the culture period. As shown in Fig. 5, deletion of Ins or EGF from DHFs medium resulted in a cell number increase similar to that in DHFs medium, whereas when $\mathrm{Tr}$ was deleted, growth was noticeably retarded and most cells eventually became detached and died. Moreover, in the absence of LA, growth was slowed to $66 \%$ of that of the DHFs medium. The deletion of BSA or Se from the DHFs medium caused complete rupture of cells within $24 \mathrm{~h}$ and after 3 days, respectively. However, even if BSA or Se was removed from DHFs medium without LA, no significant decrease in cell number occurred compared with the cell number increase in DHFs medium without LA (Fig. 5). This indicates that LA exerts cytotoxic action on the cells, while BSA and Se are required for the prevention of this cytotoxicity, although neither of them had growth-stimulating effects.

It was acertained that $\mathrm{Tr}$, when added into the basal medium with BSA and Se, exerted growth-stimulating effects in a dose-dependent manner and the action of $\mathrm{Tr}$ was effective at any concentration greater than $50 \mathrm{ng} / \mathrm{ml}$. Maximal effect was reached at $500 \mathrm{ng} / \mathrm{ml}$ (Fig. 6). Moreover, the stimulating effect synergistically increased by adding LA, although LA itself had little effect on growth (Fig. 6). A combination of $\mathrm{Tr}$ and LA exerted similar growth-stimulating effects to that in complete DHFs medium. These results indicate that $\mathrm{Tr}$ is a crucial growth-stimulating factor.

Figure 7 shows that apart from $\mathrm{Tr}, 0.5 \mu \mathrm{g} / \mathrm{ml}$ ferric ammonium citrate (FeAC) in

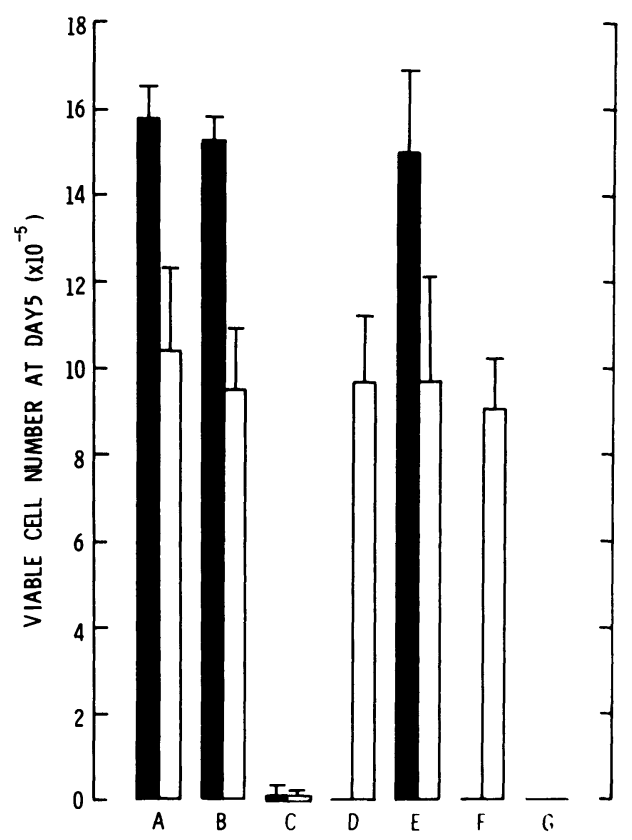

Fig. 5. Effects of supplement deletion from DHFs medium (closed column) or from DHFs medium without LA (open column) on the growth of SGE1 cells. The cells adhered on collagen type I-coated substratum (approximately $1.4 \times 10^{4}$ cells $/ 35 \mathrm{~mm}$ dish) were cultured for 5 days. Values represents the mean \pm SD of cell number $(n=6)$. A: no deletion, B: -Ins, C: -Tr, D: -Se, E: -EGF, F: -BSA, G: basal medium. 


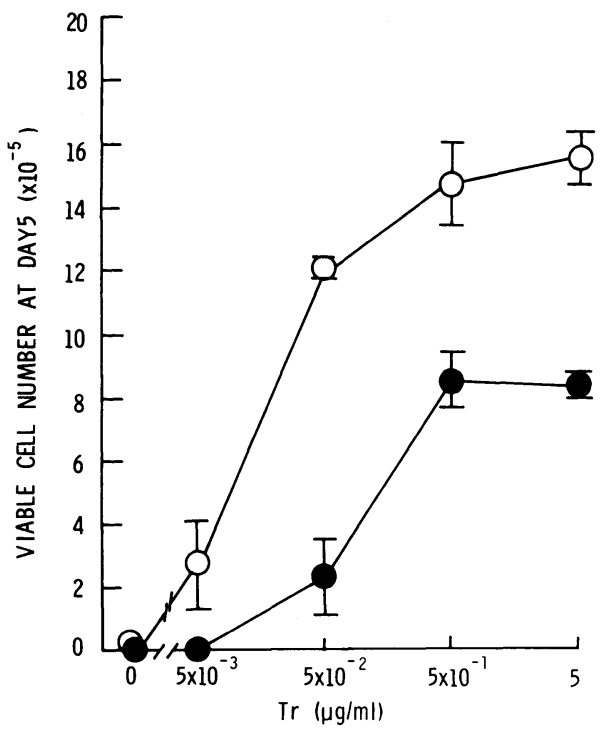

Fig. 6. Effects of Tr and/or LA on the growth of SGE1 cells. The cells adhered on the collagen type I-coated substratum (approximately $1.4 \times 10^{4}$ cells $/ 35 \mathrm{~mm} \mathrm{dish}$ ) were cultured for 5 days in various concentrations of $\operatorname{Tr}$ containing basal medium with Se $(5 \mathrm{ng} / \mathrm{ml})$ and BSA $(1 \mathrm{mg} / \mathrm{ml})$, in the presence $(O)$ or absence $(\bullet)$ of LA $(5 \mu \mathrm{g} / \mathrm{ml})$. Values represent the mean \pm SD of cell number $(n=6)$.

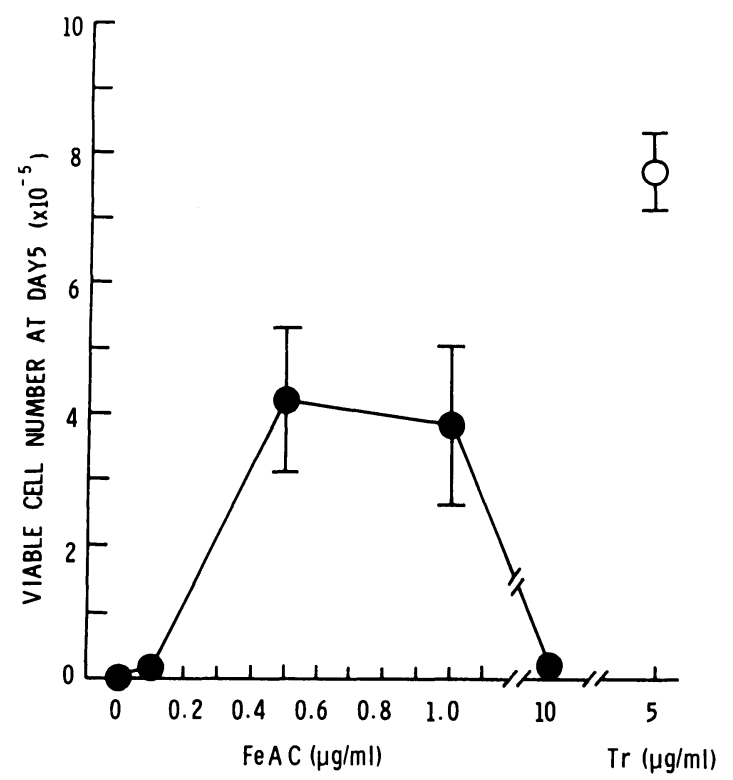

Fig. 7. Effects of FeAC on the growth of SGE1 cells. The cells adhered on collagen type I-coated substratum (approximately $1.4 \times 10^{4}$ cells $/ 35 \mathrm{~mm}$ dish) were cultured for 5 days in various concentrations of $\mathrm{FeAC}(\bullet)$ or $5 \mu \mathrm{g} / \mathrm{ml} \operatorname{Tr}(\bigcirc)$ containing basal medium with $\mathrm{Se}(5 \mathrm{ng} / \mathrm{ml})$ and BSA $(1 \mathrm{mg} / \mathrm{ml})$. Values represent the mean \pm SD of cell number $(n=6)$. 
the basal medium with BSA and Se was able to stimulate cell growth, but unlike Tr, higher concentrations of FeAC resulted in a depression of the growth rate. This suggests that the critical function of $\operatorname{Tr}$ in the growth of SGE1 cells may be in the delivery of iron to the cells because $\mathrm{Tr}$ was partially replaced by the inorganic iron.

Morphological characteristics. By light microscopy, the cells showed an epithelial morphology with typical polygonal shape and prominent nucleoli. When confluence was reached, SGE1 cells exhibited cobblestone-like sheets and formed domes or hemicysts, suggesting that they were capable of vectorial fluid transport (Fig. 1).

When ultrathin sections of the cells at confluence were viewed by electron microscopy, as shown in Fig. 8A, SGE1 cells had numerous short microvilli and cytoplasmic projections on their cell surface, junctional complexes and bundles of intermediate filaments. Figure $8 \mathrm{~B}$ shows accumulation of a basement membranelike substance in intercellular space.

We characterized SGE1 cells with respect to structural polarity in monolayer culture as a formation of domes. It has been known that cultured epithelial cells which are derived from different tissues and have potency of vectorial fluid transport can form lumina when embedded in collagen gels $(2,15,18,33,53)$. In fact, when dissociated SGE1 cells were cultured in collagen gels, the cells grew and formed compact aggregates after 7 days, after which lumina was formed within the spheres. The paraffin sections of the spheres stained with PAM confirmed this event, and showed a layer of silver-positive substances underneath the outer surface
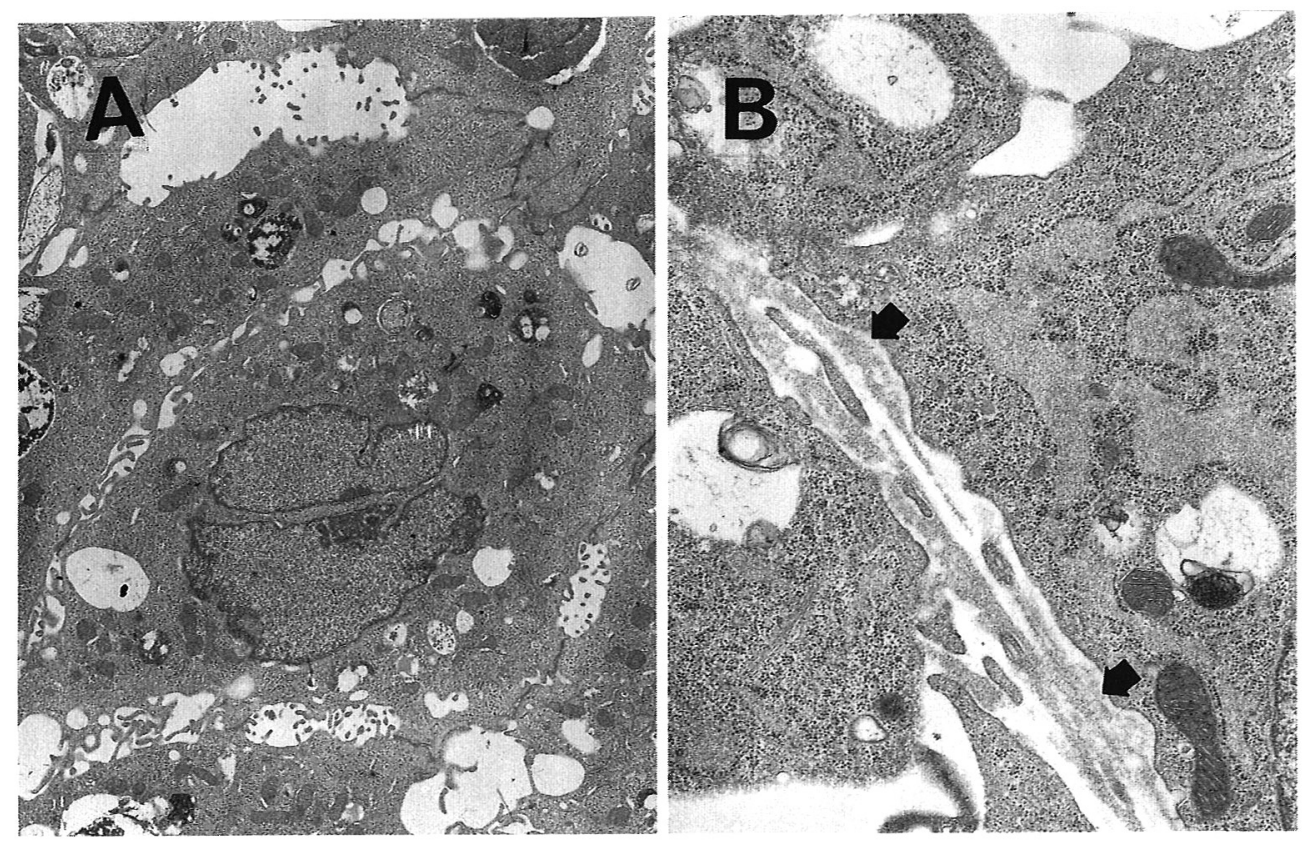

Fig. 8. Electron micrograph of SGE1 cells cultured on the collagen type I-coated substratum in DHFs medium with 10\% FCS. (A): the cells have numerous microvilli and cytoplasmic projections on the cell surface and form intercellular junctions. The cytoplasm is rich in organelles and bundles of intermediate filaments. $\times 4,000$ (B): intercellular spaces between the adjacent cells contain electron-dense material (arrow). $\times 12,000$. 


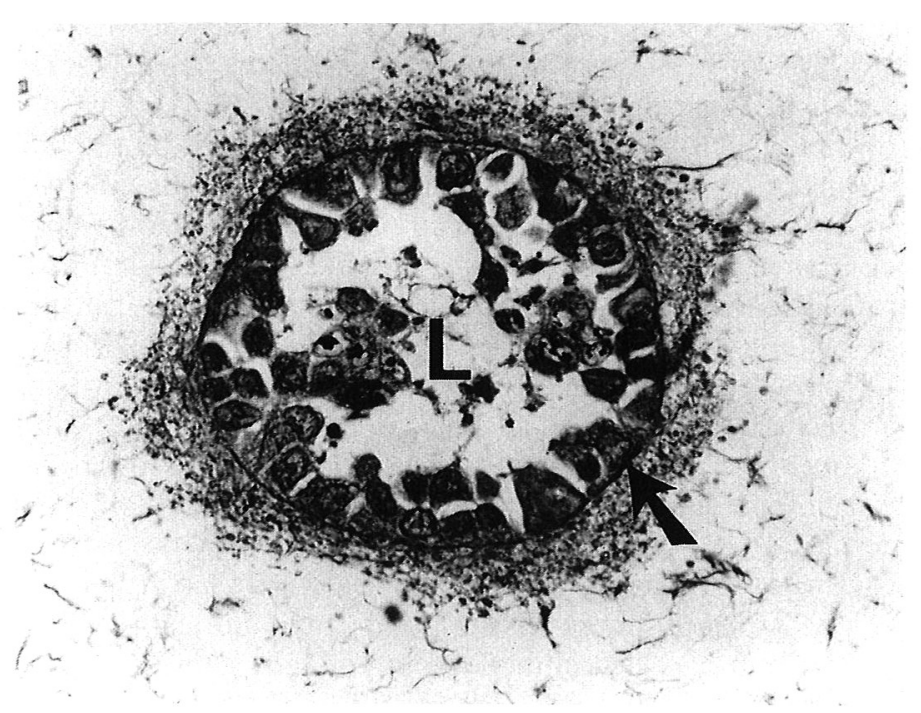

Fig. 9. Paraffin section of a cystic sphere formed of SGE1 cells. A layer of silver-positive substances (arrow), which is thought to be an extracellular matrix newly synthesized by the cells, surrounds the cystic sphere. L: lumen. PAM staining. $\times 1,200$.

of the cells (Fig. 9). The silver-positive layer is thought to be an extracellular matrix which is constructed by the cells.

Electron microscopy of SGE1 cells from constituted cystic spheres in collagen gels showed a polarized structure (Fig. 10). The cells were characterized by cuboidal cell bodies, with numerous microvilli on the luminal surface and junctional complexes (tight junctions) in the luminal region of the lateral cell membranes. There were many cytoplasmic projections in the lateral intercellular spaces. The amorphous and moderately dense materials were found just under the basal surface of the cells, which may correspond to the silver-positive substances in light microscopic observation.

Functional characteristics. In view of the results on morphological studies, we first measured activities of $\gamma$-GTP and ALP, both localized to apical membrane of transepithelial cells $(4,31,40)$.

The activities of $\gamma$-GTP and ALP in SGE1 cells were compared with those in MDCK cells. Both epithelial cells were cultured on collagen type I-coated substratum in DHFs medium with 10\% FCS until hyperconfluence occurred, then enzyme activities in these cells were measured. As shown in Table 2, both types of cells expressed activity of $\gamma$-GTP, however, that in SGE1 cells was twice as high as that in MDCK cells. ALP was not detected in SGE1 cells, whereas the enzyme was detected in MDCK cells. Because MDCK cells have been shown to possess similar levels of $\gamma$-GTP and ALP to primary cultures from purified renal proximal tubules (8), the differences in these enzyme activities between SGE1 and MDCK cells may support the idea that SGE1 cells are not contaminants from renal tubular segments.

Second, it is known that brush border antigens (Fx1A), which are capable of inducing Heymann glomerulonephritis, existed not only in proximal tubules but in glomerular epithelial cells including visceral and parietal cells $(3,6,24)$. We thus 


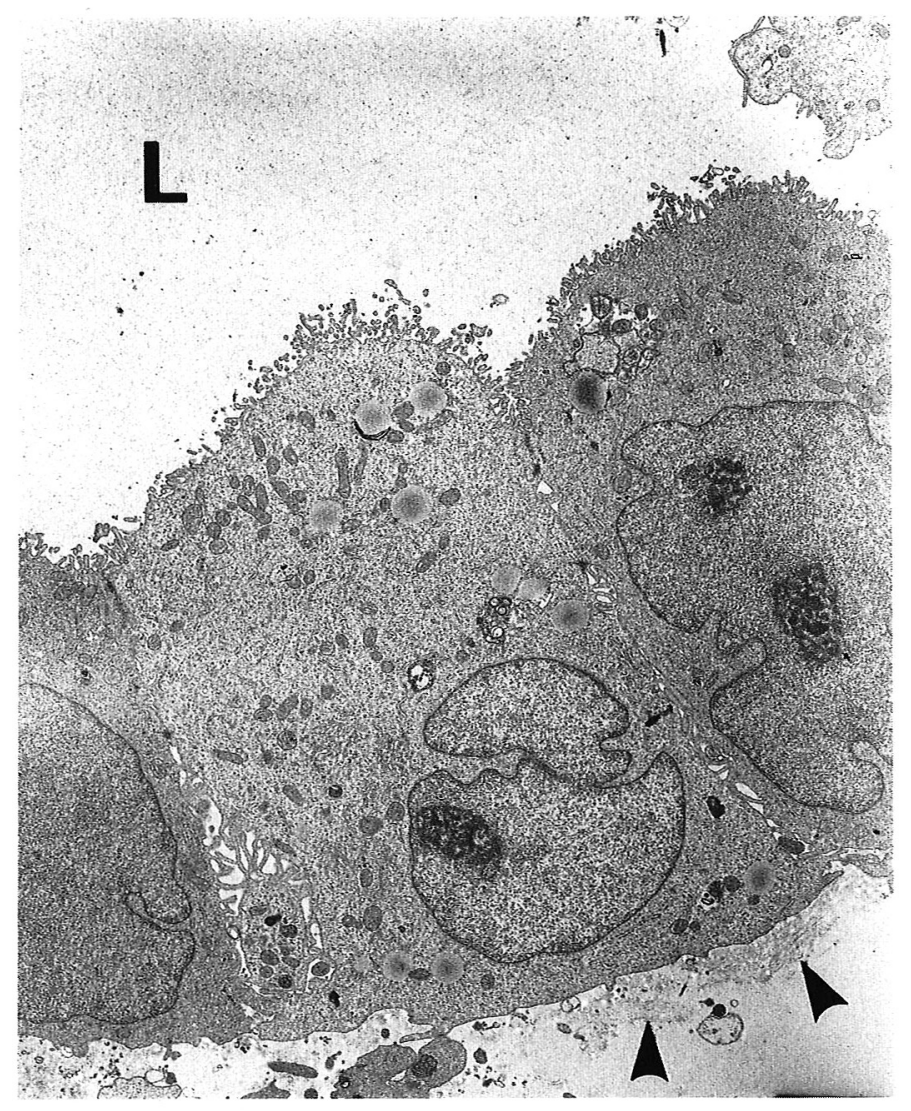

Fig. 10. Electron micrograph of SGE1 cells constituting a cystic sphere within collagen gels shows a polarized epithelial cell structure. The cells have numerous microvilli on the luminal surface and cytoplasmic projections in the lateral intercellular spaces, and tight junctions in the luminal region of the lateral membranes. The amorphous and electron-dense materials exist just under the basal cell surface (arrowhead). L: lumen. $\times 4,200$.

ascertained whether SGE1 cells contained Fx1A antigens. As shown in Fig. 11, it appeared that anti-Fx1A antigen antibodies stained the perinuclear region of the cytoplasm with a granular pattern in Nonidet P-40 treated cells. Staining also appeared on the cell surface, possibly on the microvilli. Localization of Fx1A antigens on the microvilli was confirmed by immunoelectron microscopy (Fig. 12).

Third, since rat glomerular visceral epithelial cells retain receptors for C3b (23,

TABLE 2. AlP AND $\gamma$-GTP ACTIVITIES IN CONFLUENT SGE1 AND MDCK MONOLAYERS GROWN ON A COLLAGEN TYPE I-COATED SUBSTRATUM IN DHFS MEDIUM WITH $10 \%$ FCS

\begin{tabular}{lcc}
\hline Cells & ALP (KAU $/ \mu$ g DNA $)$ & $\gamma$-GTP $(\mu \mathrm{IU} / \mu \mathrm{g}$ DNA) \\
\hline SGE1 & 0 & $519.1 \pm 7.4$ \\
MDCK & $0.9 \pm 0.2$ & 241.9 \\
\hline
\end{tabular}

Values represent the mean $\pm \operatorname{SD}(n=3)$. 

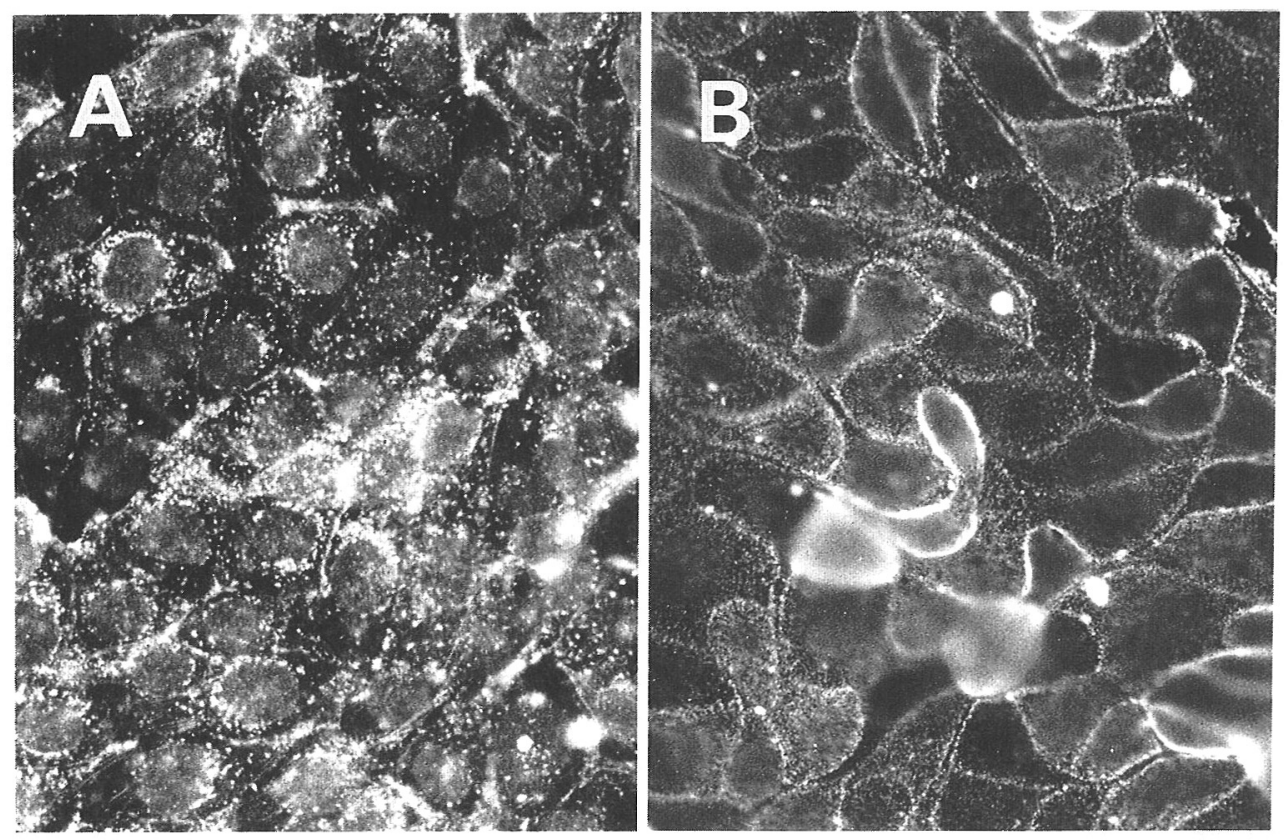

Fig. 11. Indirect immunofluorescence of SGE1 cells with (A) or without (B) permeabilization of the cell membranes which were stained for Fx1A antigens. Note the localization of Fx1A antigens in the perinuclear region of the cytoplasm (A) and on the cell surface, perhaps on the microvilli (B). A: $\times 640$, B: $\times 640$.

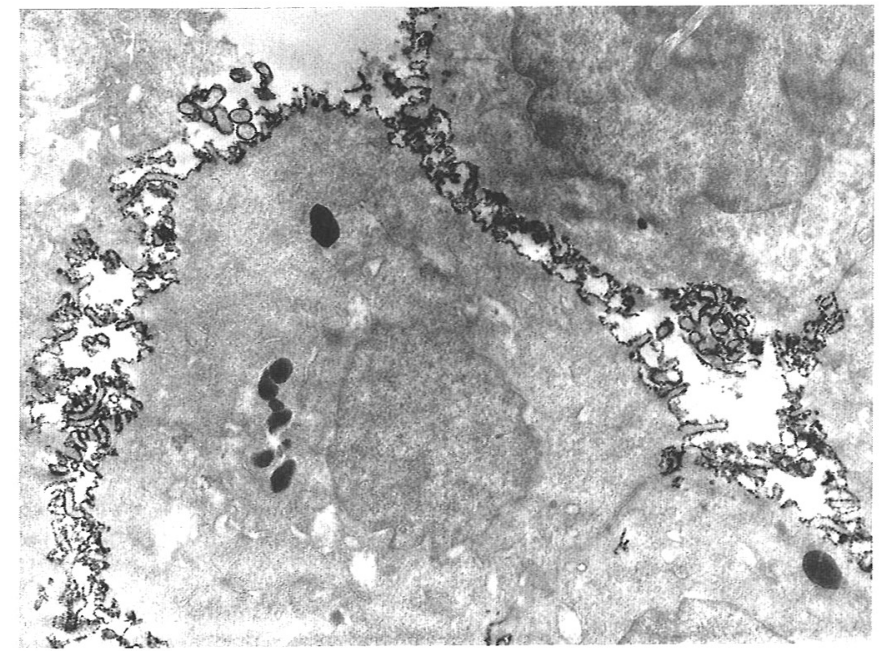

Fig. 12. Immunoelectron microscopic detection of Fx1A antigens in SGE1 cells. Note the localization of Fx1A antigens on the microvilli. $\times 6,000$. 
26), SGE1 cells were examined for these receptors. SGE1 cells in DHFs medium with or without FCS did not bind the complement coated erythrocytes, indicating that SGE1 cells do not express any C3b receptors. Furthermore, it appeared that SGE1 cells were not stained with anti-Factor VIII antibodies by indirect immunofluorescent staining, strongly suggesting that they were not endothelial in origin.

\section{DISCUSSION}

In the present study, a method has been described for establishment of a cloned epithelial cell line, designated SGE1. SGE1 was derived from isolated rat renal glomeruli, and the adhesion, growth, morphological, and functional characteristics of the SGE1 cells were investigated. Success of a epithelial cell culture has so far reported on the normal visceral epithelial cells $(19,26)$, but extended serial passage of the cells has not been described in detail. The senescence which has been reported for other glomerular and renal proximal tubular epithelial cell cultures $(17,32,35$, 37), does not seem to be applicable to SGE1 cells. One might hypothesize that SGE1 cells become neoplastically transformed. However, the cells did not show any characteristic properties of a transformed phenotype, such as chromosomal abnormality, growth in soft agar and tumor production, although about $10 \%$ of the cells did show heteroploid karyotype. Clarification of whether the SGE1 cells are derived from glomerular visceral or parietal epithelial cells, or whether they are derived from contaminants of tubular segments remains necessary.

However, it was demonstrated herein that SGE1 cells do not possess any C3b receptors, which is thought to be a property marker of glomerular visceral epithelial cells $(23,26)$, and that SGE1 cells do not express any ALP activities, which are expressed in renal tubular epithelial cell cultures including MDCK cells (8), although SGE1 cells expressed higher levels of $\gamma$-GTP activities than MDCK cells. Recently, Nörgaard $(34,35)$ classified visceral and parietal epithelial cells, which grow out from explanted glomeruli, on the basis of their morphological characteristics and growth potency. According to Nörgaard's classification, while visceral epithelial cells appeared as very large, irregular shapes with limited proliferative capacity, parietal cells appeared as small, tightly packed polygonal cells with structural characteristics similar to a simple cuboidal cell type resembling proximal tubular epithelium (12); these latter cells exhibited growth characteristics.

Thus, it is assumed that SGE1 cells are derived from the parietal epithelium of Bowman's capsule, because of their high proliferative potency and exhibiting simple cuboidal structure. Both of these characteristics comply with parietal epithelial cells in vivo $(35,38,41)$.

When SGE1 cells were cultured in DHFs medium without serum on collagen type IV-coated substratum, they grew at a growth rate similar to those in DHFs medium with 1 or $10 \%$ FCS. However, if the cells were cultured on a plain plastic substratum, the growth rate was definitely suppressed. This indicates that an appropriate substratum composed of an extracellular matrix component is required. We found, particularly, that collagen type I and IV were more potent substrata for the adhesion and growth of SGE1 cells, compared to substrata of FN and LN. However, the use of individual matrix molecules as substratum does not necessarily exert sufficient action on adhesion, growth and differentiation of a variety of epithelial cells $(14,25,47,51)$. Therefore, an in vitro reconstituted extracellular 
matrix which is composed of collagens, noncollagenous glycoproteins such as FN, LN and entactin, and proteoglycans would be expected to exert greater potency to support adhesion and growth of the cells.

Among the supplements primarily involved in the growth control of SGE1 cells are EGF, Tr and LA. Tr has been shown to exhibit growth-stimulating activity for most, if not all, cell lines grown in a serum-free medium $(1,20)$, and was also found here to be an essential growth factor for SGE1 cells. It seems likely that the role of $\mathrm{Tr}$ is to deliver iron to the cells because nontransferrin-bound iron, such as FeAC, is able to substitute partially for Tr. However, unlike Tr, FeAC at a relatively higher concentration is cytotoxic. Why FeAC cannot be completely substituted for $\mathrm{Tr}$ is unclear. It is known, however, that some iron acquired from FeAC or other iron chelates becomes cell membrane-associated (48). This then might exert cytotoxic action due to the catalyzing formation of free radicals and to promotion of lipid peroxidation of the cell membrane (13).

To our knowledge, requirement of EGF for the growth of glomerular epithelial cells is a novel finding, and the role of EGF has been defined in the present study. In contrast, Oberley et al. (36) reported that addition of EGF did not allow growth of glomerular cells resembling visceral epithelial cells. Although EGF is known to be a potent mitogen for various types of cells, the present supplement-deletion assay suggested that EGF did not act as a mitogen but acted as an adhesion-stimulating factor. Evidence is accumulating which suggests that EGF is involved in regulating membrane expression and extracellular secretion of cell adhesion-relating molecules involving extracellular matrix components. EGF has been shown to stimulate increased hyaluronic acid secretion (29) and FN synthesis by fibroblasts (7), to increase the synthesis of collagens by liver epithelial cells (28), and to stimulate increased expression of FN and LN in cancer cells of the breast (45). In a study of the growth control of rat mammary epithelial cells in a serum-free medium, EGF was shown to increase collagen type IV synthesis which accumulated as an insoluble extracellular matrix (42). Thus, EGF might stimulate adhesion of SGE1 cells together with increased membrane expression and/or extracellular secretion of adhesionrelating molecules.

Stimulating effects of both EGF and Tr on the growth of SGE1 cells were synergistically enhanced by LA, although LA itself did not exhibit stimulation of the growth. The mechanism of the enhancing effects of LA has not yet been defined. However, it is hypothesized that the effects caused by unsaturated fatty acids result from the changes in cell membrane fluidity $(10,16,43,52)$ and/or transport $(21$, 46).

Finally, an important property of SGE1 cells is possession of Fx1A antigens in the cytoplasm and on the cell surface, especially on the apical microvilli. It is known that Fx1A antigens localize on renal proximal tubules and glomerular visceral and parietal epithelial cells, and that immunization of Fx1A antigens in the rat induces Heymann nephritis which closely resembles membranous glomerulonephritis, a common type of human glomerular disease $(3,6,9,24)$. However, the precise molecular nature of Fx1A antigens, except for a glycoprotein with an apparent molecular mass of 330 kilodaltons (Gp 330) (24), has not yet been fully determined (22). Therefore, the induction mechanisms of Heymann nephritis have not been clarified either. Because SGE1 cells are able to be undergo passage for a long time and show relatively rapid growth, it would be possible to constantly provide a large supply of Fx1A antigens to biochemical and pathological studies to be used to gain 
further insight into the pathogenesis of Heymann nephritis. Thus, it is shown that in vitro culture of SGE1 cells can provide a useful method to study physiological and pathological roles of renal glomerular epithelium.

Acknowledgments. We thank Drs. S. Seno and H. Shigei, Shigei Medical Research Institute for their continuous support and expert advice regarding our research. We also thank Dr. M. Mori, Okayama University Medical School, for his comments and suggestions during the preparation of this manuscript, and Mr. S. Inoue and Mrs. F. Ueki, Shigei Medical Research Hospital for their technical assistance. This study was supported in part by the Ebitani Research Fund.

\section{REFERENCES}

1. BARnes, D. and G. SATo. Serum-free cell culture: a unifying approach. Cell 22, 649-655, 1980

2. BennetT, D.C. Morphogenesis of branching tubules in cultures of cloned mammary epithelial cells. Nature 285, 657-659, 1980

3. Bertani, T., L. Nolin, J. Foidart, A. Vandewalle and P. Verroust. The effect of puromycin on subepithelial deposits induced by antibodies directed against tubular antigens: a quantitative study. Eur. J. Clin. Invest. 9, 465-472, 1979

4. Borgers, M. The cytochemical application of new potent inhibitors of alkaline phosphatases. $J$. Histochem. Cytochem. 21, 812-824, 1973

5. Burlington, H. and E.P. Cronkite. Characteristics of cell cultures derived from renal glomeruli. Proc. Soc. Exp. Biol. Med. 142, 143-149, 1973

6. Camussi, G., J.R. Brentuens, B. Noble, D. Kerjaschio, F. Malavasi, O.A. Roholt, M.G. FarQUHAR and G. Andres. Antibody-induced redistribution of Heymann antigen on the surface of cultured glomerular visceral epithelial cells: possible role in the pathogenesis of Heymann glomerulonephritis. J. Immunol. 135, 2409-2416, 1985

7. Chen, L.B., R.C. Gudor, T.T. Sun, A.B. Chen and M.W. Mosesson. Control of a cell surface major glycoprotein by epidermal growth factor. Science 197, 776-778, 1977

8. Chung, S.D., N. Alavi, D. Livingston, S. Hiller and M. Taub. Characterization of primary rabbit kidney cultures that express proximal tubule functions in a hormonally defined medium. $J$. Cell Biol. 95, 118-126, 1982

9. Edgington, T.S., R.J. Glassock and F.J. Dixon. Autologous immune complex nephritis induced with renal tubular antigen. I. Identification and isolation of the pathogenic antigen. J. Exp. Med. 127, 555-572, 1968

10. Edidin, M. Rotational and translational diffusion in membranes. Ann. Rev. Biophys. Bioeng. 3, 199-201, 1974

11. Fiszer-Szafarz, B., D. Szafarz and A.G.D. Murillo. A general, fast, and sensitive micromethod for DNA determination: application to rat and mouse liver, rat hepatoma, human leukocytes, chicken fibroblasts, and yeast cells. Anal. Biochem. 110, 165-170, 1981

12. Foidart, J.B., C.A. Dechenne and P. Mahieu. Tissue culture of normal rat glomeruli: isolation and morphological characterization of two homogeneous cell lines. Invest. Cell. Pathol. 2, 15-26, 1979

13. Freeman, B.A. and J.D. Crapo. Biology of disease: free radicals and tissue injury. Lab. Invest. 47, 412-426, 1982

14. Fuji, D.K., S.L. Massoglia, N. Savion and D. Gospodarowicz. Neurite outgrowth and protein synthesis by $\mathrm{PC} 12$ cells as a function of substratum and nerve growth factor. J. Neurosci. 2, 11571175,1982

15. Garbi, C., A. Mascia and L. Nitsch. Cell polarity and morphogenetic properties of Fischer rat thyroid cells (FRT) cultured in suspension or embedded in different gels. Cell. Mol. Biol. 33, 293305, 1987

16. Gitler, C. Plasticity of biological membranes. Ann. Rev. Biophys. Bioeng. 1, 51-102, 1972

17. Haensly, W.E., H.J. Granger, A.C. Morris and C. Cioffe. Proximal tubule-like epithelium in Bowman's capsule in spontaneously hypertensive rats. Am. J. Pathol. 107, 92-97, 1982

18. Hall, H.G., D.A. FARSON and M.J. Bissell. Lumen formation by epithelial cell lines in response to collagen overlay: a morphogenetic model in culture. Proc. Natl. Acad. Sci. U.S.A. 79, 4672- 
4676, 1982

19. Harper, P.A., J.M. Robinson, R.L. Hoover, T.C. Wright and M.J. Karnovsky. Improved methods for culturing rat glomerular cells. Kidney Int. 26, 875-880, 1984

20. Iscove, N.N. and F. Melchers. Complete replacement of serum by albumin, transferrin and soybean lipid in culture of lipopolysaccharide- reactive B lymphocytes. J. Exp. Med. 147, 923-933, 1978

21. Kaduce, T.L., A.B. Awad, L.J. Fontenelle and A.A. Spector. Effect of fatty acid saturation on $a$-aminoisobutyric acid transport in Ehrlich ascites cells. J. Biol. Chem. 252, 6624-6630, 1977

22. Kamata, K., L.G. Baird, M.E. Erikson, A.B. Collins and R.T. McCluskey. Characterization of antigens and antibody specificities involved in Heymann nephritis. J. Immunol. 135, 2400-2408, 1985

23. Kasinath, B.S., M. MaAba and E.J. Lewis. Demonstration and characterization of C3 receptors in rat glomerular cells in culture. Kidney Int. 27, 214, 1985

24. KerJashki, D. and M.G. Farquhar. Immunocytochemical localization of the Heymann nephritis antigen (GP330) in glomerular epithelial cells of normal Lewis rats. J. Exp. Med. 157, $667-686,1983$

25. Kleinman, H.K., L. Luckenbill-Edds, F.W. Cannon and G.C. Sephel. Review: use of extracellular matrix components for cell culture. Anal. Biochem. 166, 1-13, 1987

26. Kreisberg, J.I., R.L. Hoover and M.J. Karnovsky. Isolation and characterization of rat glomerular epithelial cells in vitro. Kidney Int. 14, 21-30, 1978

27. Kreisberg, J.I. and M.J. Karnovsky. Glomerular cells in culture (editorial review). Kidney Int. 23, 439-447, 1983

28. Kumegawa, M., M. Hiramatsu, T. Yajima, K. Hatakeyama, S. Hosoda and M. Namba. Effect of epidermal growth factor on collagen formation in liver-derived epithelial clone cells. Endocrinology 110, 607-612, 1982

29. Leмвасн, K.J. Enhanced synthesis and extracellular accumulation of hyaluronic acid during stimulation of quiescent human fibroblasts by mouse epidermal growth factor. J. Cell. Physiol. 89, 277-288, 1976

30. Mackay, K., L.J. Striker, S. Elliot, C.A. Pinkert, R.L. Brinster and G.E. Striker. Glomerular epithelial, mesangial, and endothelial cell lines from transgenic mice. Kidney Int. 33, 677-684, 1988

31. Marathe, C.V., B. Nash, R.H. Haschemeyer and S.S. Tate. Ultrastructural localization of $\gamma$ glutamyltranspeptidase in rat kidney and jejunum. FEBS Lett. 107, 436-440, 1979

32. Miller, J.H. Restricted growth of rat kidney proximal tubule cells cultured in serum-supplemented and defined media. J. Cell. Physiol. 129, 264-272, 1986

33. Montesano, R., P. Mouron, M. Amherdt and L. Orci. Collagen matrix promotes reorganization of pancreatic endocrine cell monolayers into islet-like organoids. J. Cell Biol. 97, 935-939, 1983

34. NörgaARD, J.O.R. Cellular outgrowth from isolated glomeruli: origin and characterization. Lab. Invest. 48, 526-542, 1983

35. NÖRGAARD, J.O.R. Rat glomerular epithelial cells in culture: parietal or visceral epithelial origin? Lab. Invest. 57, 277-290, 1987

36. Oberley, T.D., J.V. Muth and J.E. Murphy-Ullrich. Growth and maintenance of glomerular cells under defined conditions. Am. J. Pathol. 101, 195-204, 1980

37. Oberley, T.D., A.-H. Yang and J. Gould-KostKa. Selection of kidney cell types in primary glomerular explant outgrowths by in vitro culture conditions. J. Cell Sci. 84, 69-92, 1986

38. PABST, R. and R.B. Sterzel. Cell renewal of glomerular cell types in normal rats: an autoradiographic analysis. Kidney Int. 24, 626-631, 1983

39. Patterson, M.K. Jr. Measurement of growth and viability of cells in culture. In Methods in Enzymology, Vol. 58, eds. Jakoby, W.B. and I.H. Pastan, Academic Press, New York, pp. 141-152, 1979

40. Rabito, C.A., J.I. Kreisberg and D. Wight. Alkaline phosphatase and $\gamma$-glutamyl transpeptidase as polarization markers during the organization of LLC-PK 1 cells into an epithelial membrane. J. Biol. Chem. 259, 574-582, 1984

41. RASCH, R. and J.O.R. NÖRGAARD. Renal enlargement: comparative autoradiographic studies of ${ }^{3} \mathrm{H}$-thymidine uptake in diabetic and uninephrectomized rats. Diabetologia 25, 280-287, 1983 
42. Salomon, D.S., L.A. Liotta and W.R. Kidwell. Differential response to growth factor by rat mammary epithelium plated on different collagen substrata in serum-free medium. Proc. Natl. Acad. Sci. U.S.A. 78, 382-386, 1981

43. Spector, A. and J.M. Soborff. Utilization of free fatty acids complexed to human plasma lipoproteins by mammalian cell suspensions. J. Lipid Res. 12, 545-552, 1971

44. Striker, G.E. and L.J. Striker. Glomerular cell culture. Lab. Invest. 53, 122-131, 1985

45. Thorne, H.J., D.G. Jose, H.-Y. Zhang, P.J. Dempsey and R.H. Whitehead. Epidermal growth factor stimulates the synthesis of cell-attachment proteins in the human breast cancer cell line PMC42. Int. J. Cancer 40, 207-212, 1987

46. Van Deenen, L.L.M. Permeability and topography of membranes. Chem. Phys. Lipids 8, 366373, 1972

47. Vlodavsky, I., G.M. Lui and D. Gospodarowicz. Morphological appearance, growth behavior and migratory activity of human tumor cells maintained on extracellular matrix versus plastic. Cell 19, 607-616, 1980

48. White, G.P. and A. JACOBS. Iron uptake by Chang cells from transferrin, nitrilotriacetate and citrate complexes. Biochim. Biophys. Acta 543, 217-225, 1978

49. Wicha, M.S., G. Lowrie, E. Kohn, P. Bagavandoss and T. Mahn. Extracellular matrix promotes mammary epithelial growth and differentiation in vitro. Proc. Natl. Acad. Sci. U.S.A. 79, 3213-3217, 1982

50. Yamada, M., M. Kawaguchi, H. TakamiYa and T. OKigaki. Glomerular epithelial cells in serum-free culture. Soshikibaiyo 13, 7-12, 1987 (in Japanese)

51. Yamada, M., T. OKigaki and M. Awai. Adhesion and growth of rat liver epithelial cells on an extracellular matrix with proteins from fibroblast conditioned medium. Cell Struct. Funct. 12, 53-62, 1987

52. Yamane, I. and F. Tomioka. The concomitant effect of unsaturated fatty acid supplemented to medium on cellular growth and membrane fluidity of cultured cells. Cell Biol. Int. Rep. 3, 515-523, 1979

53. YANG, J., L. LARSON and S. NANDI. Three-dimensional growth and morphogenesis of mouse submandibular epithelial cells in serum-free primary culture. Exp. Cell Res. 137, 481-485, 1982

(Received for publication, September 6, 1988) 